The Journal of Animal \& Plant Sciences, 31(3): 2021, Page: 854-861

ISSN (print): 1018-7081; ISSN (online): 2309-8694

\title{
BENTHIC MACROINVERTEBRATES AND PHYSICOCHEMICAL VARIABLES OF STREAMS IN THE GULI RIVER NATIONAL WETLAND PARK, GREATER KHINGAN MOUNTAINS, NORTHEAST CHINA
}

\author{
E. I. Shabani1,2, M.H. Liu ${ }^{1 *}$, H.X. Yu ${ }^{1 *}$, J-B. B. Muhigwa ${ }^{2}$, W. A. Ekoko ${ }^{1}$ and C. Jingjing ${ }^{1}$ \\ ${ }^{1}$ Department of Ecology, College of Wildlife and Protected Area, Northeast Forestry University, Harbin P.O. Box \\ 150040, China. \\ ${ }^{2}$ Départment of Biology, Faculty of Sciences, State University of Bukavu, P.O. Box 570-Bukavu, Democratic Republic \\ of the Congo. \\ *Corresponding author’s email: manhong@nefu.edu.cn, china.yhx@163.com
}

\begin{abstract}
This preliminary study aimed to identify benthic macroinvertebrates, and test the relationships of macroinvertebrate functional feeding groups (FFGs) and environmental parameters in the stream environments of the Guli River National Wetland Park. We used square-frame net to collect benthic macroinvertebrate populations and multi-parameter probe to measure water temperature, conductivity, $\mathrm{pH}$, chlorine, turbidity, ammonium, nitrate and chlorophyll $a$ in situ. We analyzed total nitrogen and total phosphorus in the lab following American Public Health Association (APHA) protocols. We used the canonical correspondence analysis (CCA) to test the correlations of stream community FFGs with physicochemical variables. We caught a total of 64 macroinvertebrate species and measured ten environmental variables at eight sites in both seasons (summer and autumn). Among macroinvertebrates, we identified more insects (50 species) in both seasons. Benthic macroinvertebrate abundance $(\mathrm{p}=0.6966)$, taxa richness $(\mathrm{p}=0.1122)$, Shannon diversity $\left(H^{\prime}, \mathrm{p}=0.0762\right)$ and Pileou's evenness $\left(J^{\prime}, \mathrm{p}=0.7922\right)$ were similar at all sites between two seasons. Water temperature, chlorine, $\mathrm{NH}_{4}{ }^{+}, \mathrm{NO}_{3}{ }^{-}$, turbidity, $\mathrm{TN}$ and TP were high during summer, while chlorophyll $a$, conductivity and $\mathrm{pH}$ increased during autumn. Our CCA results showed that the metrics of abundance of gathering-collectors had significant relationships with total phosphorus, total nitrogen, nitrate and conductivity. The findings also shed light on predators, shredders and filter-collectors and their positive correlations with $\mathrm{pH}$, turbidity, ammonium, chlorine and chlorophyll $a$ in stream environments.
\end{abstract}

Keywords: canonical correspondence analysis (CCA), environmental parameters, functional feeding groups (FFGs), macroinvertebrates, mountain streams .

\section{INTRODUCTION}

Macroinvertebrates form an integral part of aquatic ecosystems, and allow for the detection of a variety of disturbances in stream environments (Moore and Palmer, 2005), and are widely useful indicators of stream health monitoring programs (Lenat, 1988; Grant et al., 1993). They form also an important food source for numerous vertebrates, especially fish, birds and amphibians. They are threatened by several anthropogenic pressures combined with changes in some natural factors, such as hydrological regime, water temperature, light level, water chemistry (Vannote and Sweeney, 1980), feeding resources, and stream ecosystem heterogeneity (Beisel et al., 2000). These factors influence the seasonal variations of benthic macroinvertebrate and changes in species related to life history strategy in several stream environments (Rempel et al., 2000).

Macroinvertebrate monitoring programs can help in the development of appropriate guidelines for conservation (Davis et al., 2003). The knowledge of functional group of benthic macroinvertebrate community in stream biotopes is an important for understanding of energy flow, organic-matter processing, trophic associations and conservation actions needed to minimize the impairment of stream functioning (Benstead and Pringle, 2004).

Aquatic systems of the streams of Guli River National Wetland Park are unknown, because no previous study was ever conducted on benthic macroinvertebrate populations in this area. This survey intended to identify benthic macroinvertebrates, and test the relationships of macroinvertebrate functional feeding groups (FFGs) and physicochemical variables in the stream environments of the Guli River National Wetland Park.

\section{MATERIALS AND METHODS}

Study area: The Guli River National Wetland Park is located in the Greater Khingan Mountains between the Heilongjiang Province and Inner Mongolia Autonomous 
Region in Northeast China. The Greater Khingan Mountains extend between $\mathrm{N} 50^{\circ} 10^{\prime}$ and $53^{\circ} 33^{\prime}$ and between $\mathrm{E} 121^{\circ} 12^{\prime}$ and $127^{\circ} 00^{\prime}$ (Chen et al., 2014). The Guli River National Wetland Park covers around 28,702 hectares, of which 15,846 hectares are freshwater wetlands. There are some fish species with high economic value, such as Brachymystax lenok, Hucho taimen, and Esox reicherti, and some amphibian species, including Rana amurensis, Bufo raddei, and Bufo gargarizans.

Sampling and laboratory procedures: During sampling campaign, we selected eight stream sites of the Guli River National Wetland Park according, and used GPS (Garmin) to determine the study site coordinates (Table1). We used Water Quality Multiprobes to measure water temperature $\left({ }^{\circ} \mathrm{C}\right)$, electric conductivity $\left(\mu \mathrm{Scm}^{-1}\right)$, $\mathrm{pH}$, chlorine $\left(\mathrm{mgL}^{-1}\right)$, turbidity (NTU), ammonium $\left(\mathrm{mgL}^{-1}\right)$, nitrate $\left(\mathrm{mgL}^{-1}\right)$, and chlorophyll $a\left(\mathrm{mgL}^{-1}\right)$ in situ during summer and autumn in 2018 . We took $500 \mathrm{ml}$ of water samples at all stream sites in both seasons using bottles, and transported to the lab of Hydrobiology, Northeast Forestry University to analyze respectively total nitrogen $\left(\mathrm{mgL}^{-1}\right)$, and total phosphorus $\left(\mathrm{mgL}^{-1}\right)$ following APHA protocols (APHA, 2012).

Stream macroinvertebrate communities were captured using square-frame net at the same time physicochemical parameters were measured in situ. We replicated three times to sample benthic macroinvertebrates at each site in both seasons and we sieved caught individuals using a sieve in the field to separate them from sand, mud and substrates. And then we fixed all collected individuals in labelled plastic bottles containing $95 \%$ ethanol for further lab processing.

In the lab, we used a dissecting microscope at 20× magnification and keys of Qi (1996); Zhou et al. (2015); Lu et al. (2017) to identify benthic macroinvertebrate taxa. We classified our stream macroinvertebrate species into five FFGs according to their trophic specialization (Merritt et al., 1996), including predators (PR), gathering-collectors (GC), shredders (SH), filtering-collectors (FC), and scrapers (SC).

Table 1. Eight study sites (latitude " $N$ " and longitude "E").

\begin{tabular}{ccc}
\hline Sampling site & $\mathbf{N}$ & $\mathbf{E}$ \\
\hline 1 & $50^{\circ} 24^{\prime} 48.43^{\prime \prime}$ & $124^{\circ} 06^{\prime} 44.92^{\prime \prime}$ \\
2 & $50^{\circ} 36^{\prime} 51.85^{\prime \prime}$ & $124^{\circ} 47^{\prime} 29.38^{\prime \prime}$ \\
3 & $50^{\circ} 39^{\prime} 12.05^{\prime \prime}$ & $124^{\circ} 45^{\prime} 56.47^{\prime \prime}$ \\
4 & $50^{\circ} 40^{\prime} 53.03^{\prime \prime}$ & $124^{\circ} 43^{\prime} 59.97^{\prime \prime}$ \\
5 & $50^{\circ} 34^{\prime} 50.85^{\prime \prime}$ & $122^{\circ} 20^{\prime} 12.69^{\prime \prime}$ \\
6 & $50^{\circ} 40^{\prime} 12.66^{\prime \prime}$ & $124^{\circ} 37^{\prime} 34.04^{\prime \prime}$ \\
7 & $50^{\circ} 34^{\prime} 45.62^{\prime \prime}$ & $124^{\circ} 19^{\prime} 45.01^{\prime \prime}$ \\
8 & $50^{\circ} 34^{\prime} 50.49^{\prime \prime}$ & $124^{\circ} 19^{\prime} 30.07^{\prime \prime}$ \\
\hline
\end{tabular}

Statistical analysis: We calculated macroinvertebrate species diversity for each site in both seasons using Shannon-Wiener ( $H^{\prime}$, Shannon 1948) and Pielou's evenness indices $\left(J^{\prime}\right.$, Pielou 1966).

Shannon-Wiener diversity $\left(H^{\prime}\right)=-\sum_{i-1}^{S} P$

Pielou's evenness $\left(J^{\prime}\right)=\frac{H^{\prime}}{l_{1}}$

Where $\Sigma=$ sum from species 1 to species $\mathrm{S}, S$ is the number of species, $P i$ is the proportion of individuals of the $i$ species in sample, $\ln$ is the logarithm to base e.

As well as we used PAST software (version 2. 17, Hammer, 2012) to calculate macroinvertebrate abundance and taxa richness. We contrasted physicochemical variable, macroinvertebrate abundance, taxa richness, $H^{\prime}$ and $J^{\prime}$ between summer and autumn using paired t-test in $\mathrm{R}$ software. We computed the CCA to test the relationships of water parameters and macroinvertebrate FFGs using vegan package in $R$ software. We used also the principal component analysis (PCA) in $\mathrm{R}$ software (RcmdrPlugin.FactorMine R package) to explore the correlations between stream sites and environmental variables.

\section{RESULTS AND DISCUSSION}

Environmental parameters: We recorded high values of water temperature, chlorine, $\mathrm{NH}_{4}{ }^{+}, \mathrm{NO}_{3}{ }^{-}$, turbidity, total nitrogen and total phosphorus in summer (Table 2). While chlorophyll $a$, conductivity, and $\mathrm{pH}$ were reported higher in autumn. Paired t-test results showed that water temperature and conductivity $(\mathrm{p}<0.05)$ and $\mathrm{pH}, \mathrm{TN}(\mathrm{p}<$ $0.01)$, significantly changed between summer and autumn. Unlike chlorine, $\mathrm{NH}_{4}{ }^{+}, \mathrm{NO}_{3}^{-}$, turbidity, chlorophyll $a$, and TP which did not change significantly with seasons $(p>0.05)$. Niba and Sakwe (2018) also recorded high water temperature values in summer season at Kambi in the Mthatha River. On the contrary, the mean values of turbidity and NO3- and NH4+ concentrations were higher in autumn in the Pas river basin, Cantabria, northern Spain (Álvarez-Cabria et al., 2010). We observed that the streams of the Greater Khingan Mountains tended to be neutral in summer, and the increase of stream temperature in summer may accelerate aquatic macrophyte growth and, subsequently, promotes the process of organic matter production.

The PCA performed for eight sites and ten water physicochemical parameters explained the variances of the first two axes (30.52\% and $24.61 \%)$, with eigenvalues 3.05 and 2.46, respectively. PCA results showed that environmental parameters varied at the sites according to seasons. We found that $\mathrm{NH}_{4}^{+}$, total phosphorus, temperature, and turbidity were the highest at site in summer on first axis, while the highest values of $\mathrm{pH}$ were recorded at sites $1,3,4,5$, and 6 in autumn on second axis (Fig. 1). 
Table 2. The stream physicochemical characterization in the two seasons investigated.

\begin{tabular}{lcccc}
\hline Physicochemical factors & Summer & Autumn & $\boldsymbol{t}$ & $\boldsymbol{p}$ \\
\hline Chlorine $\left(\mathrm{Cl}^{-}, \mathrm{mgL}^{-1}\right)$ & $70.41 \pm 26.89$ & $47.67 \pm 12.93$ & 2.1583 & 0.0677 \\
Ammonium $\left(\mathrm{NH}_{4}^{+}, \mathrm{mgL}^{-1}\right)$ & $0.52 \pm 0.78$ & $0.05 \pm 0.02$ & 1.6836 & 0.1361 \\
Nitrate $\left(\mathrm{NO}_{3}^{-}, \mathrm{mgL}^{-1}\right)$ & $0.05 \pm 0.07$ & $0.02 \pm 0.01$ & 1.5474 & 0.1657 \\
Turbidity $(\mathrm{NTU})$ & $3.60 \pm 1.12$ & $3.04 \pm 1.23$ & 0.7670 & 0.4682 \\
Chlorophyll $a\left(\mathrm{Chl} a, \mathrm{mgL}^{-1}\right)$ & $3.68 \pm 2.58$ & $3.77 \pm 1.84$ & -0.0797 & 0.9387 \\
Total phosphorus $\left(\mathrm{TP}, \mathrm{mgL}^{-1}\right)$ & $0.17 \pm 0.11$ & $0.11 \pm 0.09$ & 1.7083 & 0.1313 \\
Total nitrogen $\left(\mathrm{TN}, \mathrm{mgL}^{-1}\right)$ & $9.70 \pm 5.42$ & $2.39 \pm 0.96$ & 4.1460 & $0.0043^{* *}$ \\
pH & $7.23 \pm 0.56$ & $8.30 \pm 0.36$ & -4.1979 & $0.0040^{* *}$ \\
Water temperature $\left(\mathrm{WT},{ }^{\circ} \mathrm{C}\right)$ & $14.76 \pm 2.72$ & $12.38 \pm 1.17$ & 2.7656 & $0.0278^{*}$ \\
Conductivity $\left(\mathrm{Cond}, \mu \mathrm{Scm}^{-1}\right)$ & $50.5 \pm 26.05$ & $67.38 \pm 22.12$ & -2.7710 & $0.0276^{*}$ \\
\hline
\end{tabular}

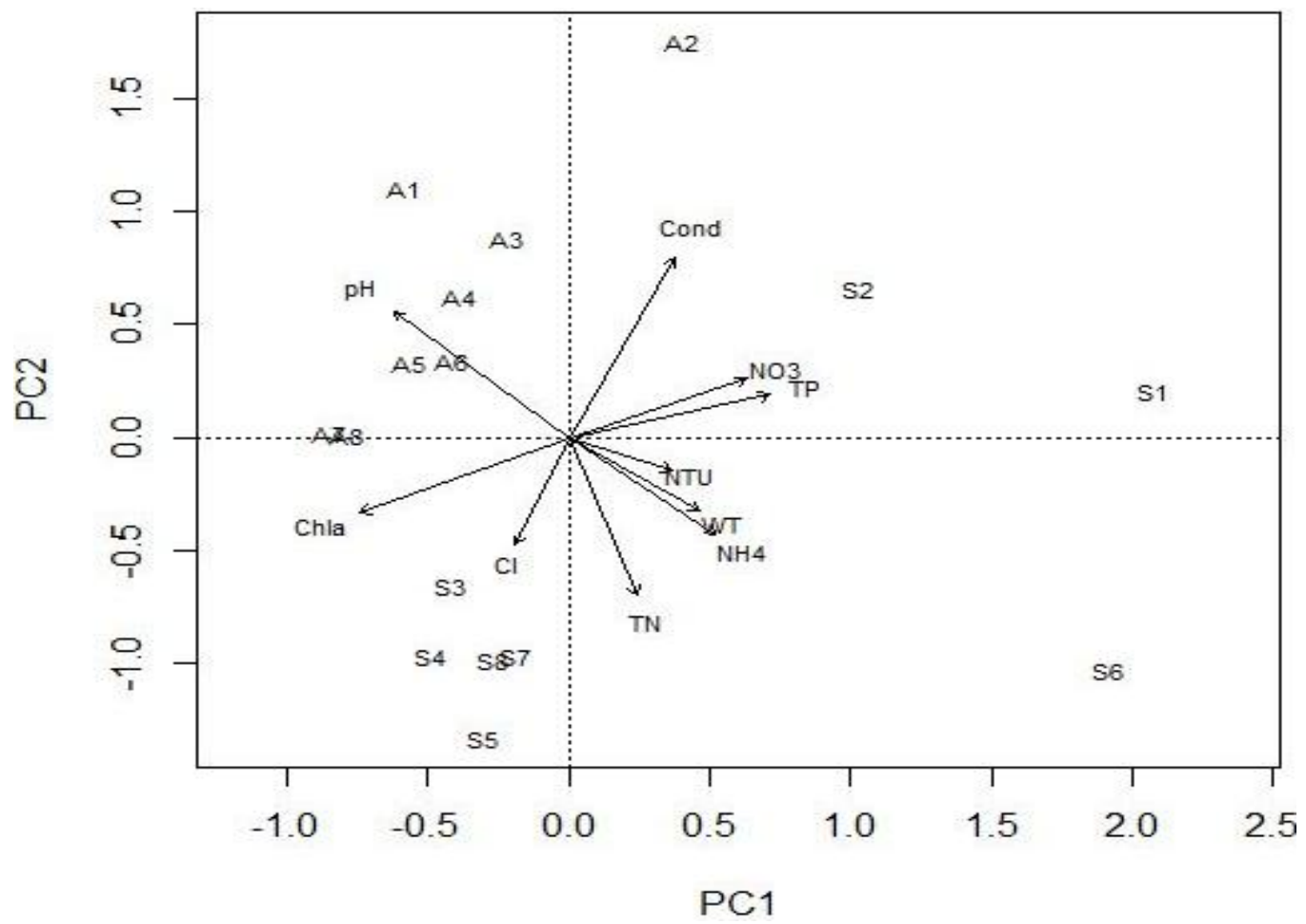

Figure 1. Principal Component Analysis showing the correlations stream sites-environmental variables $(\mathrm{A}=$ autumn and $\mathrm{S}=$ summer). WT= water temperature, $\mathrm{Cond}=$ conductivity, $\mathrm{NTU}=$ turbidity, $\mathrm{Cl}^{-}=$ chlorine, $\mathrm{Chl} a=$ chlorophyll $a, \mathrm{NH}_{4}{ }^{+}=$ammonium, $\mathrm{NO}_{3}{ }^{-}=$nitrate, $\mathrm{TN}=$ total nitrogen, $\mathrm{TP}=\quad$ total phosphorus.

Benthic macroinvertebrate community composition: During summer and autumn, we collected 998 specimens, belonging to 64 species. $55.71 \%$ of specimens were caught in summer belonging to 41 taxa and $44.29 \%$ captured in autumn belonging to 45 species (Table 3 ). We captured more insects (with 50 species) at all sites in both seasons, and among them, Siphlonurus sp. (Ephemeroptera) was the mostly recorded with scores up to $24.45 \%$ followed by Baetis sp. (Ephemeroptera) with $20.54 \%$ and Anabolia bimaculata (Trichoptera) with
$13.33 \%$. Siphlonurus sp. was only collected in summer. It was observed that many benthic macroinvertebrates, especially insect species were caught at the stream sites dominated abundantly by aquatic macrophytes. Paired ttest results indicated that macroinvertebrate abundance and taxa richness (Fig. 2a, b) were similar at stream sites in both seasons ( $\mathrm{p}=0.6966$ and $\mathrm{p}=0.1122$, respectively). Figure 2 (c, d) also showed that the diversity indices $H^{\prime}(\mathrm{p}$ $=0.0762)$ and $J^{\prime}(\mathrm{p}=0.7922)$ did not also differ significantly at all sampling sites in both seasons. 
Table 3. Stream macroinvertebrate species and relative abundances in the two seasons investigated. FFGs $=$ functional feeding groups, $\mathrm{SH}=$ shredders, $\mathrm{SC}=$ scrapers, $\mathrm{FC}=$ filtering-collectors, $\mathrm{GC}=$ gatheringcollectors, $\mathbf{P R}=$ predators.

\begin{tabular}{|c|c|c|c|c|}
\hline \multirow[t]{2}{*}{ Taxon } & \multirow[t]{2}{*}{ FFGs } & \multicolumn{3}{|c|}{$\%$ of total individuals } \\
\hline & & Summer & Autumn & Total \\
\hline \multicolumn{5}{|l|}{ Coleoptera } \\
\hline Agabus sp. & PR & & 0.20 & 0.20 \\
\hline Haliplidae & SH/PR & 0.40 & 0.10 & 0.50 \\
\hline \multicolumn{5}{|l|}{ Diptera } \\
\hline Apsectrotanypus sp. & PR & 0.10 & 1.20 & 1.30 \\
\hline Brillia bifida Kieffer, 1909 & SH & 0.20 & & 0.20 \\
\hline Chironomus anthracinus Zetterstedt, 1860 & $\mathrm{GC}$ & 0.20 & & 0.20 \\
\hline Chironomus circumdatus Kieffer, 1916 & $\mathrm{GC}$ & 0.40 & & 0.40 \\
\hline Cricotopus annulator Goetghebuer, 1927 & $\mathrm{GC}$ & 0.00 & 0.20 & 0.20 \\
\hline Cryptochironomus supplicans Kieffer, 1913 & PR & 0.10 & & 0.10 \\
\hline Cyphomella cornae Sæther, 1977 & $\mathrm{GC}$ & & 0.10 & 0.10 \\
\hline Cyphomella sp. & $\mathrm{GC}$ & 0.80 & & 0.80 \\
\hline Dicranomyia sp. & SH & 0.10 & & 0.10 \\
\hline Dicrotendipes sp. & $\mathrm{GC}$ & 0.10 & & 0.10 \\
\hline Holorusia sp. & SH & 0.20 & & 0.20 \\
\hline Natarsia nugax Walker, 1856 & PR & 0.10 & & 0.10 \\
\hline Orthocladius sp. & $\mathrm{GC}$ & & 0.40 & 0.40 \\
\hline Procladius sp. & PR & 0.40 & & 0.40 \\
\hline Stictochironomus akizukii Tokunaga, 1940 & $\mathrm{GC}$ & 0.10 & & 0.10 \\
\hline Thienemannia gracilis Kieffer, 1911 & GC & & 0.10 & 0.10 \\
\hline Tipula sp. & SH & 0.30 & 0.40 & 0.70 \\
\hline Zalutschia sp. & GC & 0.20 & 0.70 & 0.90 \\
\hline \multicolumn{5}{|l|}{ Ephemeroptera } \\
\hline Baetis sp. & GC & 3.21 & 17.33 & 20.54 \\
\hline Brachycercus sp. & $\mathrm{GC}$ & 0.90 & & 0.90 \\
\hline Caenis sp. & $\mathrm{GC}$ & 1.10 & 0.10 & 1.20 \\
\hline Cloeon sp. & $\mathrm{GC}$ & & 0.20 & 0.20 \\
\hline Ecdyonurus sp. & $\mathrm{GC}$ & & 0.30 & 0.30 \\
\hline Ephemera sp. & $\mathrm{GC}$ & 0.10 & 0.70 & 0.80 \\
\hline Ephemerella sp. & $\mathrm{GC}$ & 0.70 & & 0.70 \\
\hline Metreplecton sp. & PR & 2.20 & 0.10 & 2.30 \\
\hline Serratella $\mathrm{sp}$. & $\mathrm{GC}$ & & 1.70 & 1.70 \\
\hline Siphlonurus sp. & $\mathrm{GC}$ & 24.45 & & 24.45 \\
\hline \multicolumn{5}{|l|}{ Hemiptera } \\
\hline Aquarius elongatus Uhler, 1896 & PR & 0.10 & 0.10 & 0.20 \\
\hline \multicolumn{5}{|l|}{ Hygrophila } \\
\hline Gyraulus convexiusculus Hutton, 1849 & $\mathrm{SC}$ & 2.10 & 2.10 & 4.20 \\
\hline Radix auricularia Linnaeus, 1758 & $\mathrm{SC}$ & & 0.20 & 0.20 \\
\hline Radix ovata Draparnaud, 1805 & $\mathrm{SC}$ & 1.30 & 0.20 & 1.50 \\
\hline Radix swinhoei Yen, 1936 & $\mathrm{SC}$ & 0.60 & 0.80 & 1.40 \\
\hline Valvata piscinalis O. F. Müller, 1774 & $\mathrm{SC}$ & 1.20 & 0.70 & 1.90 \\
\hline \multicolumn{5}{|l|}{ Littorinimorpha } \\
\hline Bithynia fuchsiana Möllendorff, 1888 & $\mathrm{SC}$ & 1.00 & 0.60 & 1.60 \\
\hline \multicolumn{5}{|l|}{ Megaloptera } \\
\hline Protohermes sp. & $\mathrm{PR}$ & 0.10 & & 0.10 \\
\hline Sialis sibirica McLachlan, 1872 & PR & 0.20 & 0.40 & 0.60 \\
\hline \multicolumn{5}{|l|}{ Odonata } \\
\hline Lestidae & SH & & 0.10 & 0.10 \\
\hline Macromia sp. & $\mathrm{PR}$ & 0.80 & 1.40 & 2.20 \\
\hline Sinictinogomphus sp. & PR & & 0.10 & 0.10 \\
\hline
\end{tabular}




\begin{tabular}{|c|c|c|c|c|}
\hline \multicolumn{5}{|l|}{ Plecoptera } \\
\hline Isogenus sp. & $\mathrm{GC}$ & 0.10 & & 0.10 \\
\hline Isoperla sp. & PR & & 0.90 & 0.90 \\
\hline Nemoura sp. & $\mathrm{SH}$ & & 0.10 & 0.10 \\
\hline Perlodini sp. & PR & 0.10 & 0.20 & 0.30 \\
\hline Phanoperla sp. & PR & 0.60 & 1.10 & 1.70 \\
\hline Suwallia sp. & PR & & 0.20 & 0.20 \\
\hline \multicolumn{5}{|l|}{ Rhynchobdellida } \\
\hline Helobdella пиda Moore, 1924 & PR & & 0.30 & 0.30 \\
\hline Helobdella stagnalis Linnaeus, 1758 & PR & & 0.20 & 0.20 \\
\hline Hemiclepsis sp. & PR & & 0.20 & 0.20 \\
\hline Parabdella quadrioculata Fairmaire, 1895 & PR & & 0.10 & 0.10 \\
\hline \multicolumn{5}{|l|}{ Trichoptera } \\
\hline Anabolia bimaculata Walker, 1852 & SH & 9.12 & 4.21 & 13.33 \\
\hline Apatania sp. & $\mathrm{SC}$ & & 0.50 & 0.50 \\
\hline Brachycentrus sp. & $\mathrm{FC}$ & 0.63 & 1.00 & 1.63 \\
\hline Clostoeca sp. & SH & & 1.00 & 1.00 \\
\hline Dicosmoecus sp. & $\mathrm{SC}$ & 0.30 & & 0.30 \\
\hline Limnephilidae & $\mathrm{SH} / \mathrm{SC}$ & & 0.50 & 0.50 \\
\hline Micrasema sp. & SH & 0.30 & 1.30 & 1.60 \\
\hline Phryganeidae & $\mathrm{SH} / \mathrm{SC}$ & & 0.90 & 0.90 \\
\hline \multicolumn{5}{|l|}{ Tubificida } \\
\hline Limnodrilus helveticus Piguet, 1913 & $\mathrm{GC}$ & 0.20 & & 0.20 \\
\hline Tubificidae & $\mathrm{GC}$ & 0.10 & & 0.10 \\
\hline \multicolumn{5}{|l|}{ Unionoida } \\
\hline Potamilus capax Green, 1832 & $\mathrm{FC}$ & 0.00 & 0.15 & 0.15 \\
\hline \multicolumn{5}{|l|}{ Veneroida } \\
\hline Sphaerium sp. & $\mathrm{FC}$ & 0.50 & 0.90 & 1.40 \\
\hline
\end{tabular}

Benthic macroinvertebrate functional feeding groups associated with physical and chemical characteristics: Figure 4 shows the first and second CCA explained $41.0 \%$ and $24.7 \%$ of variance, with eigenvalues of 0.2301 and 0.1385 . The CCA indicated a significant correlation of environmental variables and benthic FFG structure within the stream sites in both seasons. Among benthic FFG assemblages, Gathering-collectors were the most collected at all sites in both summer and autumn (Fig. 3), with scores up to $55.4 \%$, followed by shredders with $17.8 \%$, scrapers $(11.9 \%)$, predators $(11.8 \%)$, and filtercollectors represented smaller fractions (3.2\%). Our functional feeding group results were similar to those recorded by Pan et al. (2013); Fogelman et al. (2018), where gathering-collectors were found the most abundant in the Yangtze River and the Susquehanna River, respectively. Jung et al. (2008) also recorded the dominance of gathering-collectors in temperate stream systems of East Asia.

The CCA findings displayed a positive correlation of total phosphorus, total nitrogen, nitrate and conductivity with distribution of gathering-collectors and community structures of sites 2 and 3 in summer, and at sites 2, 7, and 8 in autumn on the first axis. Souto et al. (2012) highlighted the presence of high conductivity values may be an indirect sign of pollution within the sites. Results also showed that $\mathrm{pH}$, turbidity, ammonium, chlorine, and chlorophyll $a$ are positively correlated with distribution of predators, shredders and filter-collectors, and species composition of sites $4,6,7$, and 8 in summer, and at sites 4, 5, and 6 in autumn on the second axis.

Benthic faunal communities differently respond to water physicochemical properties by controlling their distribution and abundance, and determining their composition within habitats (King and Richardson, 2007). In this study, mayflies (Ephemeroptera) were more collected in summer (about 32.7\%) than in autumn (20.4\%). Cowan and Oswood (1984) indicated that the abundance of benthic macroinvertebrate fauna was low in mid-summer, and increased in late summer and autumn due to recruitment from the hatching in the temperate streams. Water temperature is often considered the essential factor that contributes to the marked seasonality in benthic macroinvertebrate communities in stream systems (Halwas et al., 2005). According to the "intermediate disturbances" theory, seasonal changes in water temperature increase species richness and maintain maximum species abundance (Chi et al., 2017).

During both seasons, we collected more Ephemeroptera, Plecoptera, Trichoptera, and Odonata, which are pollution-sensitive species (Eaton and Lenat, 1991; Lenat, 1988). While higher numbers of pollutiontolerant species of Diptera, Gastropoda and Oligochaeta (Cheimonopoulou et al., 2010) were recorded in summer 
than in autumn. Cheimonopoulou et al. (2010) recorded pollution-sensitive species of Trichoptera and pollutiontolerant species of Diptera in early autumn in small Mediterranean. We highlight that gathering-collectors,
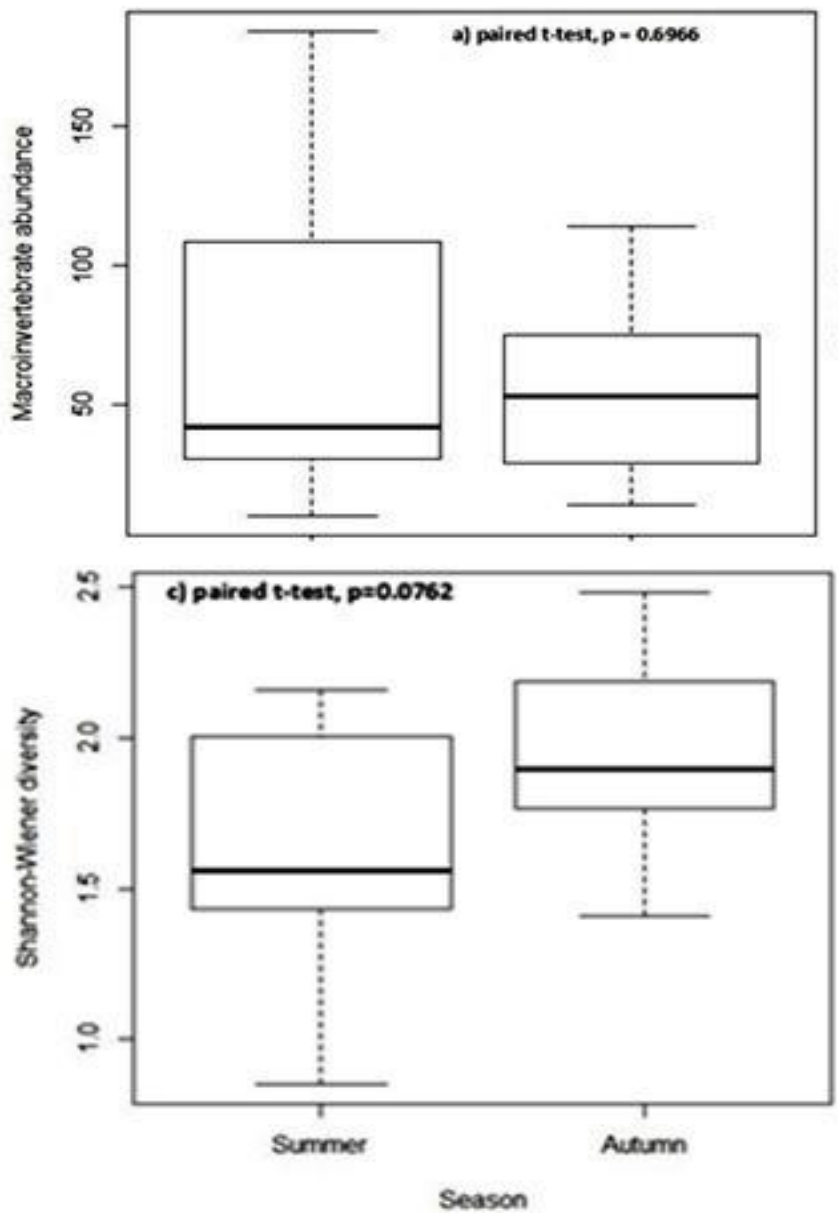

such as aquatic Oligochaeta and Chironomidae (Diptera) are tolerant to disturbance and pollution in the stream ecosystem.
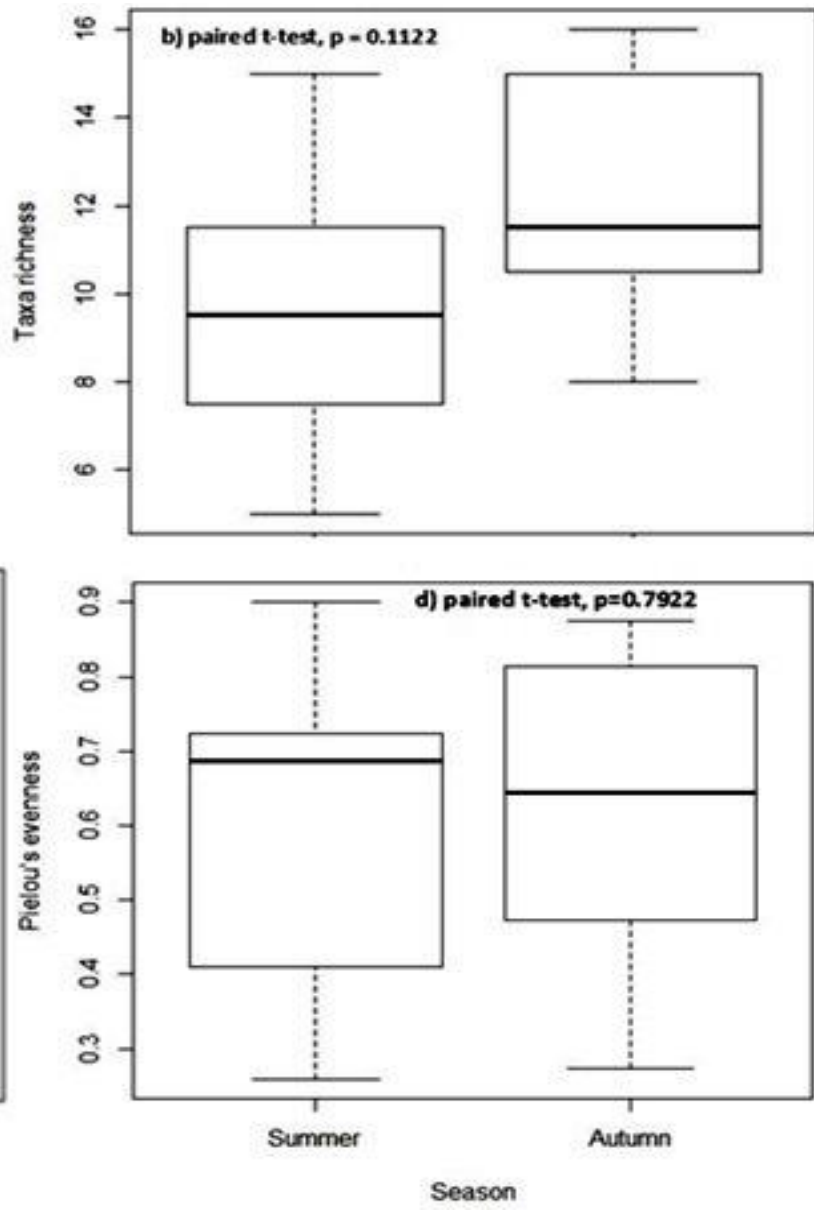

Figure 2. Comparison of mean values of macroinvertebrates in summer and autumn.

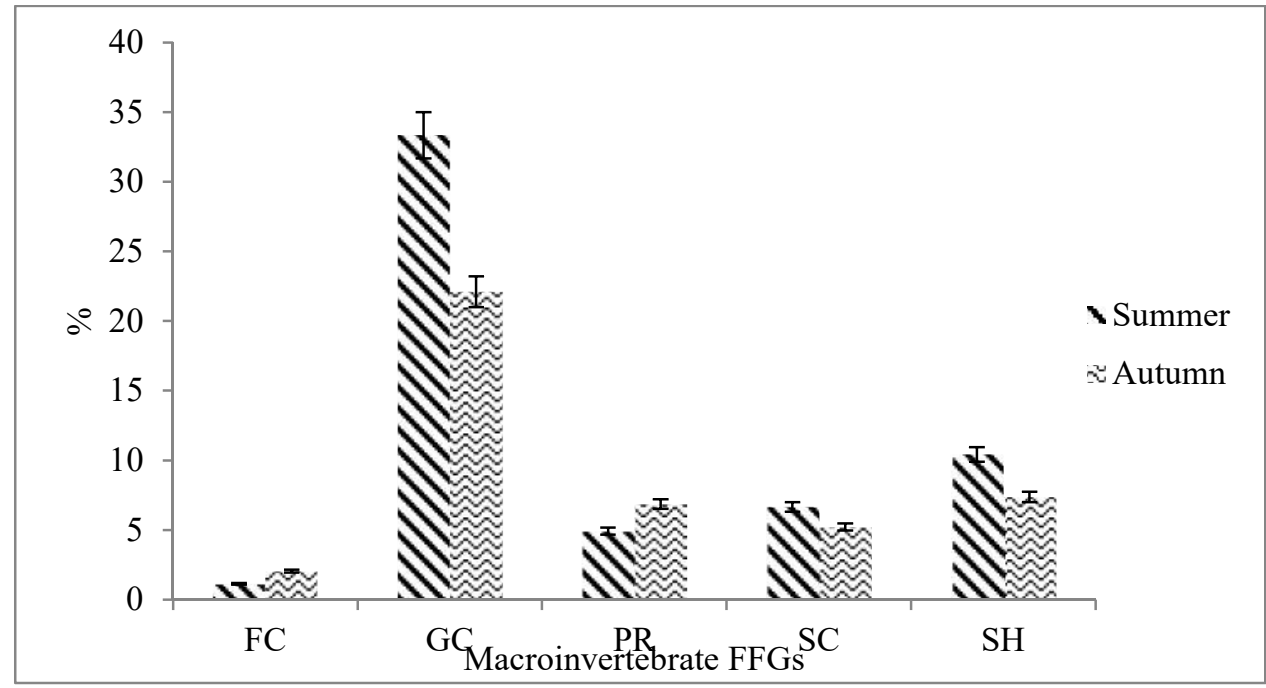

Figure 3. Percentage of benthic community FFGs recorded in both seasons. FC $=$ filtering-collectors, GC $=$ gathering-collectors, $\mathbf{P R}=$ predators, $\mathrm{SC}=$ scrapers, $\mathrm{SH}=$ shredders. 


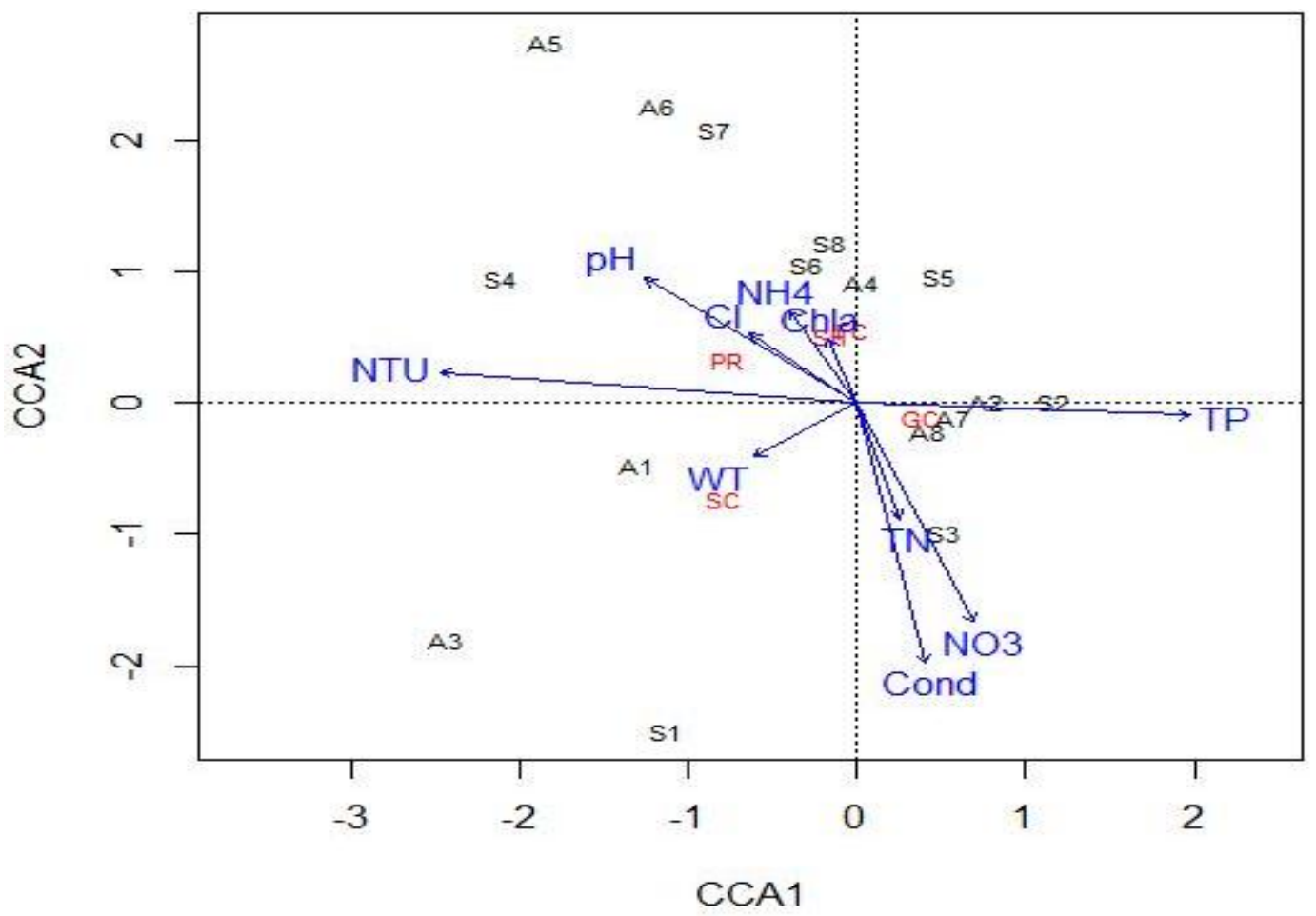

Figure 4. CCA) lot showing the association of steam sites-environmental factors-benthic community FFGs in both autumn (A) and summer (S). WT= water temperature, Cond = conductivity, $\mathbf{N T U}=\quad$ turbidity, $\mathrm{Cl}^{-}$ $=$ chlorine, $\mathrm{Chl} a=$ chlorophyll $a, \mathrm{NH}_{4}{ }^{+}=$ammonium, $\mathrm{NO}_{3}{ }^{-}=$nitrate, $\mathrm{TN}=$ total nitrogen, $\mathrm{TP}=$ total phosphorus, $\mathrm{SH}=$ shredders, $\mathrm{SC}=$ scrapers, $\mathrm{FC}=$ filtering-collectors, $\mathrm{GC}=$ gathering-collectors, $\mathbf{P R}=$ predators.

Conclusion: In this preliminary survey of stream environments, we identified 64 benthic macroinvertebrate species, belonging to 5 functional feeding groups. We sampled more gathering-collectors at all stream sites in both summer and autumn. The metrics of macroinvertebrates abundance, species richness, diversity indices $H^{\prime}$ and $J^{\prime}$ were similar between these two seasons over the sampling sites. The findings of this study shed some light on benthic community FFGs and their correlations with environmental characteristics in stream ecosystem of Guli River National Wetland Park. These results may suggest a conservation need of stream macroinvertebrates in the Greater Khingan Mountains.

Acknowledgements: This research was financed by The National Key Research and Development Program of China "typical fragile ecological restoration and protection research" (Fund No. 2016YF0500406) is gratefully acknowledged. We also thank Yucheng Sun, Vice Director from Dobukuer National Reserve, for his assistance during the sampling procedures.

\section{REFERENCES}

Álvarez-Cabria, M., J. Barquín and A.J. Juanes (2010). Spatial and seasonal variability of macroinvertebrate metrics: Do macroinvertebrate communities track river health? Ecol. Indic. 10(2): 370-379.

APHA (2012). Standard methods for the examination of water and wastewater, 22nd edition edited by Rice EW, Baird RB, Eaton AD, Clesceri LS. American Public Health Association (APHA), American Water Works Association (AWWA) and Water Environment Federation (WEF), Washington, D.C., USA. 1496 p

Beisel, J.N., P. Usseglio-Polatera and J.C. Moreteau (2000). The spatial heterogeneity of a river bottom: a key factor determining macroinvertebrate communities. Hydrobiology, 422:163-171.

Benstead, J.P. and C.M. Pringle (2004). Deforestation alters the resource base and biomass of endemic stream insects in eastern Madagascar. Freshw. Biol. 49:490-501.

Cheimonopoulou, M.T., D.C. Bobori, I. Theocharopoulos and M. Lazaridou (2010). Assessing Ecological Water Quality with Macroinvertebrates and Fish: A Case Study from a Small Mediterranean. River. Environ. Manag. 47:279-290.

Chen, W., K. Moriya, T. Sakai, L. Koyama and C. Cao (2014). Post-fire forest regeneration under 
different restoration treatments in the Greater Hinggan Mountain area of China. Ecol. Eng. 70:304-311.

Chi, S., S. Li, S. Chen, M. Chen, J. Zheng and J. Hu (2017). Temporal variations in macroinvertebrate communities from the tributaries in the Three Gorges Reservoir Catchment, China. Rev. Chil. Hist. Nat. 90:111.

Cowan, C.A. and M.W. Oswood (1984). Spatial and seasonal associations of benthic macroinvertebrates and detritus in an Alaskan subarctic stream. Polar. Biol. 3:211-215.

Davis, S., S.W. Golladay, G. Vellidis and C.M. Pringle (2003). Macroinvertebrate Biomonitoring in Intermittent Coastal Plain Streams Impacted by Animal Agriculture. J. Environ. Qual. 32: 10361043.

Eaton, L.E. and D.R. Lenat (1991). Comparison of a rapid bioassessment method with North Carolina's qualitative macroinvertebrate collection method. J. N. Am. Benthol. Soc. 10:335-338.

Fogelman, K.J., M.D. Bilger, J.R. Holt and D.P. Matlaga (2018). Decomposition and benthic macroinvertebrate communities of exotic Japanese knotweed (Fallopia japonica) and American sycamore (Platanus occidentalus) detritus within the Susquehanna River. J. Freshw. Ecol. 33(1), 299-310.

Grant, I.F., I.C. Simpson, P.A. Roger and R. Oficial (1993). Invertébrés aquatiques. Natural Resources Institute, University of Greenwich at Medway, Central Avenue, Chatham Maritime, Kent ME4 4TB, R-U. pp. 183-193.

Halwas, K.L., M. Church and J.S. Richardson (2005). Benthic assemblage variation among channel units in high-gradient streams on Vancouver Island, British Columbia. J. North. Am. Benthol. Soc. 24:478- 494.

Hammer, Ø. (2012). PAST-PAlaeontological Statistics, version 2. 17. Reference manual, Natural History Museum, University of Oslo. $229 \mathrm{p}$

Jung, S.W., V.V. Nguyen, Q.H. Nguyen and Y.J. Bae (2008). Aquatic insect faunas and communities of a mountain stream in Sapa Highland, northern Vietnam. Limnology, 9:219-229.

King, R.S. and C.J. Richardson (2007). Subsidy-stress response of macroinvertebrate community biomass to a phosphorus gradient in an oligotrophic wetland ecosystem. J. North. Am. Benthol. Soc. 26:491-508.
Lenat, D.R. (1988). Water quality assessment of streams using a qualitative collection method for benthic acroinvertebrates. J. North. Am. Benthol. Soc. $7: 222-233$

Lu, J., T. Huo and X. Wang (2017). Benthc Macroinvertebrates of Songliao River and Ecological Research. Jilin Univ. 214 p (in Chinese)

Merritt, R.W., K.W. Cummins and M.B. Berg (1996). An Introduction to the Aquatic Insects of North America, 3rd Edition. Kendall/Hunt Publishing Company: Dubuque, Iowa, USA. $862 \mathrm{p}$

Moore, A.A. and P.M. Palmer (2005). Invertebrate biodiversity in agricultural and urban headwater streams: implications for conservation and management. Ecol. Appl. 15:1169-1177.

Niba, A. and S. Sakwe (2018). Turnover of benthic macroinvertebrates along the Mthatha River, Eastern Cape, South Africa: implications for water quality bio-monitoring using indicator species. J. Freshw. Ecol. 33(1), 157-171.

Pan, B., Z. Wang, Z. Li, G. Yu, M. Xu, N. Zhao and G. Brierley (2013). An exploratory analysis of benthic macroinvertebrates as indicators of the ecological status of the Upper Yellow and Yangtze Rivers. J. Geogr. Sci. 23:871-882.

Pielou, E.C. (1966). The measurement of diversity in different types of biological collections. J. Theor. Biol. 13:131-144.

Qi, Z. (1996). Economic Mollusca of China. China Agriculture Press. 325 p (in Chinese)

Rempel, L.L., J.S. Richardson and M.C. Healey (2000). Macroinvertebrate community structure along gradients of hydraulic and sedimentary conditions in a large gravel-bed river. Freshw. Biol. 45:57-73.

Shannon, C.E. (1948). Mathematical theory of communication. Bell. Syst .Tech. J 27, 379-423, 623-656.

Souto, R.M.G., K.G. Facure, L.A. Pavanin and G.B. Jacobucci (2012). Influence of environmental factors on benthic macroinvertebrate communities of urban streams in Vereda habitats, Central Brazil. Acta. Limnol. Bras. 23:293-306.

Vannote, R.L. and B.W. Sweeney (1980). Geographic analysis of thermal equilibria: a conceptual model for evaluating the effect of natural and modified thermal regimes on aquatic insect communities. Am. Nat. 115:667-695.

Zhou, C., C. Su and H. Gui (2015). Outline of Chinese Mayflies. Science Press, Beijing, China. 310 p (in Chinese). 